\title{
Bioremediation of Cadmium and Chromium Metal Polluted Soil Using Compost
}

\author{
Rusmini ${ }^{1}$, Sukarmin, Muchlis \\ Chemistry Department \\ Universitas Negeri Surabaya \\ Surabaya, Indonesia \\ ${ }^{1}$ Rusmini@unesa.ac.id
}

\begin{abstract}
Research on remediation of chromium and cadmium metal contaminated soil using compost has been carried out. Added compost was 5\%, 10\%, 15\%, $20 \%$ and $25 \%$ w/w. The study was conducted for 14 days and observed a decrease in the concentration of heavy metals in the soil. Measurement of heavy metal concentrations using AAS Perkin Elmer instrument. Based on the results of the analysis, the highest chromium decrease was $92.222 \%$ and the highest cadmium was $90.551 \%$ in the use of $25 \%$ compost.
\end{abstract}

\section{Keywords-chromium, cadmium, bioremediation, compost}

\section{INTRODUCTION}

Soil pollution can occur with the entry of heavy metals into the environment. Heavy metals in the long term will accumulate in the environment and provide great health risks for living things. The Agency for the Toxic Substances and Disease Registry (ATSDR) has shown chromium and cadmium as highly toxic heavy metals. Cadmium's toxicity is greater than chromium. [1,2]. Heavy metals can enter the body of an organism through passive diffusion, intra/inter-cell active transport and endocytosis. The metal can be distributed and accumulated between organs and tissues [3-5]. The amount of metal accumulation that enters the tissue/organ is affected by the absorption and elimination rates of the metal. Heavy metal toxicity depends on the type, content, synergyantagonist effect and chemical physical properties. The greater concentration of heavy metals the greater the toxicity.

Chromium $(\mathrm{Cr})$ can harm the environment even though it is only present in small quantities. Chromium is stable and accumulates in the body so that over time it can trigger cancer cells (carcinogenic), disorders of the genital urinary system, nervous system, liver, respiratory tract, and skin [6-8] which can endanger health. Cadmium $(\mathrm{Cd})$ causes central nervous and peripheral nerve disorders. In certain doses it can cause symptoms of neuropathy, muscle atrophy and myelin degeneration in mice. Cadmium also inhibits the chemical transmission of the neuromuscular junction. This effect results in inhibition of calcium $(\mathrm{Ca})$ function in nerve terminals and causes a reduction in presynaptic acetyl choline release as a neurotransmitter of nerve endings. Cd toxicity also causes less interference from reflex response, hypoactivity, impaired coordination and decreased learning activities. Effects on the respiratory system: chronic bronchitis, progressive fibrosis in the lower respiratory tract and septal rupture between alveoli caused by emphysema [1][6].

A chemical laboratory in Surabaya East Java does not have a waste water treatment plant (WWTP). Waste water from laboratory activities containing heavy metals is discharged through domestic waste streams. In the soil around the laboratory there are already many plants, but do not produce fruit. This reinforces the suspicion of heavy metal pollution in the soil. Through testing using the AAS instrument, it was found that the soil in the environment around the chemical laboratory contained chromium of $1.8 \mathrm{ppm}$ and cadmium $0.254 \mathrm{ppm}$. The content is still below the critical limit of heavy metal elements in the soil, Cd $0.01 \mathrm{ppm}$ and $\mathrm{Cr} 0.5 \mathrm{ppm}$ [9]. However, chromium and cadmium are heavy metals that are not allowed because they are toxic and accumulative so they are harmful to human health [10]. The data shows the entry of chromium and cadmium metal pollutants on the soil so that a treatment needs to be done.

In the previous study, the use of EM4 (effective microorganism 4) was used as a bioremediatory of heavy metals chromium and cadmium on the ground. EM4 can reduce chromium up to $93.111 \%$ and cadmium $49.213 \%$ [11]. EM4 contains microorganisms commonly used as additives or bio activators in composting [12][13]. In this study compost was used as a bioremediatory. Compost is often used to improve soil structure, increase plant growth, maintain water content, and increase soil microbial activity [14][15]. Compost is the result of decomposing organic materials with the help of microbes. The use of compost is considered more effective as a soil bioremediatory because it also improves soil structure. It's expected that using compost as a bioremediatory can provide multiple benefits, namely improving soil structure and reducing heavy metals in polluted soil.

\section{RESEARCH METHODS}

\section{A. Materials}

Materials used include soil taken from the sample location, leaf compost and $1 \% \mathrm{HNO}_{3}$. The equipment used includes glassware, Whatman 42 filter paper, Perkin Elmer AAS instrument, and Shimadzu Infrared spectroscopy instrument. 


\section{B. Research Steps}

One hundred grams of soil sample that has been known to be initially mixed with compost with a variation of $5 \%, 10 \%$, $15 \%, 20 \%$ and $25 \%(\mathrm{w} / \mathrm{w})$ are put into polybags. It also prepared land without treatment as a control. After 14 days, the soil was measured by its $\mathrm{Cr}$ and $\mathrm{Cd}$ concentration. 10 grams of soil taken plus $50 \mathrm{~mL}$ of $1 \% \mathrm{HNO}_{3}$ soaked and filtered. The filtrate was measured with AAS to determine the residual $\mathrm{Cr}$ and $\mathrm{Cd}$ content. Then the percentage of the decrease in heavy metal content was calculated.

Sample measurement used Perkin Elmer AAS instrument. Measurements of $\mathrm{Cd}$ and $\mathrm{Cr}$ were carried out respectively at a wavelength of $228.8 \mathrm{~nm}$ and $357.9 \mathrm{~nm}$. The data obtained in the form of absorbance data. The absorbance data is then converted to concentration data. The measured concentration is the concentration of residual metal from the sample. Infrared (IR) spectroscopy is also used to determine the soil functional groups used before and after bioremediation.

\section{RESEARCH AND DISCUSSION}

The percentage reduction in cadmium and chromium metals was calculated by reducing the initial concentration with the residual concentration obtained by measuring with the Perkin Elmer AAS instrument. Table I shows the results of the percentage reduction in heavy metal chromium and cadmium in the use of compost for 14 days.

TABLE I.

PERCENT DECREASING OF HEAVY METAL

\begin{tabular}{|c|c|c|}
\hline \multirow{2}{*}{$\begin{array}{c}\text { Amount of } \\
\text { compost (\%) }\end{array}$} & \multicolumn{2}{|c|}{ Percentage of heavy metal reduction (\%) } \\
\cline { 2 - 3 } & Cadmium & Chromium \\
\hline 5 & 73.622 & 92.611 \\
\hline 10 & 76.378 & 93.222 \\
\hline 15 & 84.646 & 93.333 \\
\hline 20 & 89.764 & 96.444 \\
\hline 25 & 90.551 & 92.222 \\
\hline Control & 37.008 & 83.667 \\
\hline
\end{tabular}

Based on the data in Table I it can be seen that the percentage of cadmium and chromium metal decreases. The use of more compost increases the amount of heavy metal lost. This is because with more and more compost used, the more availability of microbes in the soil. Microbes play a role in degrading heavy metals through binding of metal ions to microbial cell walls. The ions that were originally present in the microbial cell wall will exchange with heavy metal ions from contaminated soil. The next process is the formation of ionic complexes between heavy metals and functional groups contained in the microbial wall including carbonyl, amino, thiol, hydroxy, phosphate, and hydroxy carbonyl [16].

Increasing availability of compost causes increased soil moisture. Compost is hydrophilic so it increases the ability of the soil to bind water. This soil moisture helps microbes develop well. Microbes use heavy metals as energy sources so that microbes will survive in conditions on polluted soil. Metals in the form of insoluble salts will be deposited and immobilized in the cell wall. Microbial cells are able to produce chelating agents and change the permeability of microbial cell membranes to metals so that the metal changes shape to be non-toxic [17]. Figure 1 shows the hypothetical reaction between chromium and microbes. In the control treatment of soil contaminated with heavy metals without the addition of compost there was also a decrease in heavy metals. This was because naturally there are microbes that live in the soil. The addition of compost increases the number of soil microbes so that the percentage of heavy metal reduction is greater than without the addition of compost.

Besides containing microbes, compost also contains humus substances. Humus substance dominates the final product from compost. Humus substance is resistant to degradation by microorganisms [18]. Humus substance plays a major role in the adsorption process. The humus substances are humid acid and fulvic acid [19]. The adsorption process occurs through the exchange of anion cations, hydrogen bonds [20, 21], electrostatic bonds and chelating formation [22-24]. The bond that causes the heavy metal is difficult to return to release.

Based on the reaction in Figure 1, it shows the cell wall membrane when it encounters heavy metals will release lactic acid which functions as chelating heavy metals. In the cell wall there is a carbonyl functional group. This carbonyl group can bind to heavy metals. Through the metabolic process the bacteria secrete lactic acid. Lactic acid chelates heavy metals to form heavy metal complexes and escape from the cell wall.

Based on the data in Table 1 it can be said that in general the percent decrease in cadmium is lower than that of chromium metal. This can be explained using the HSAB (hard soft acid base) theory. According to the HSAB theory cadmium as soft acid and chromium are classified as hard acids. Lactic acid and hydroxyl released by microbes are hard bases. Between hard acids and hard bases form ionic bonds. The bond between soft acids and hard bases is a covalent bond. The rate of interaction of compounds with ionic bonds is faster than compounds with covalent bonds. This is what causes chromium to decrease faster than cadmium.

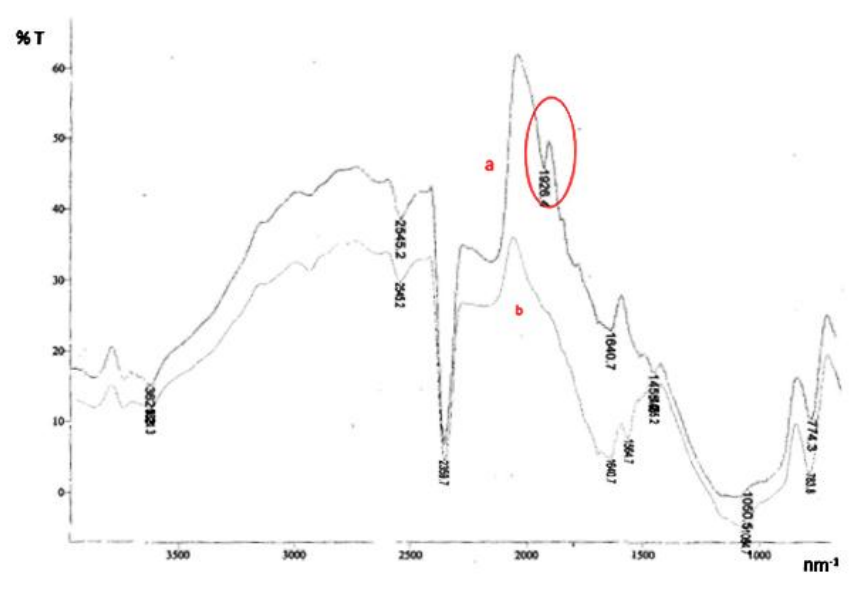

Fig 1. IR soil spectra before (a) and after (b) bioremediation 


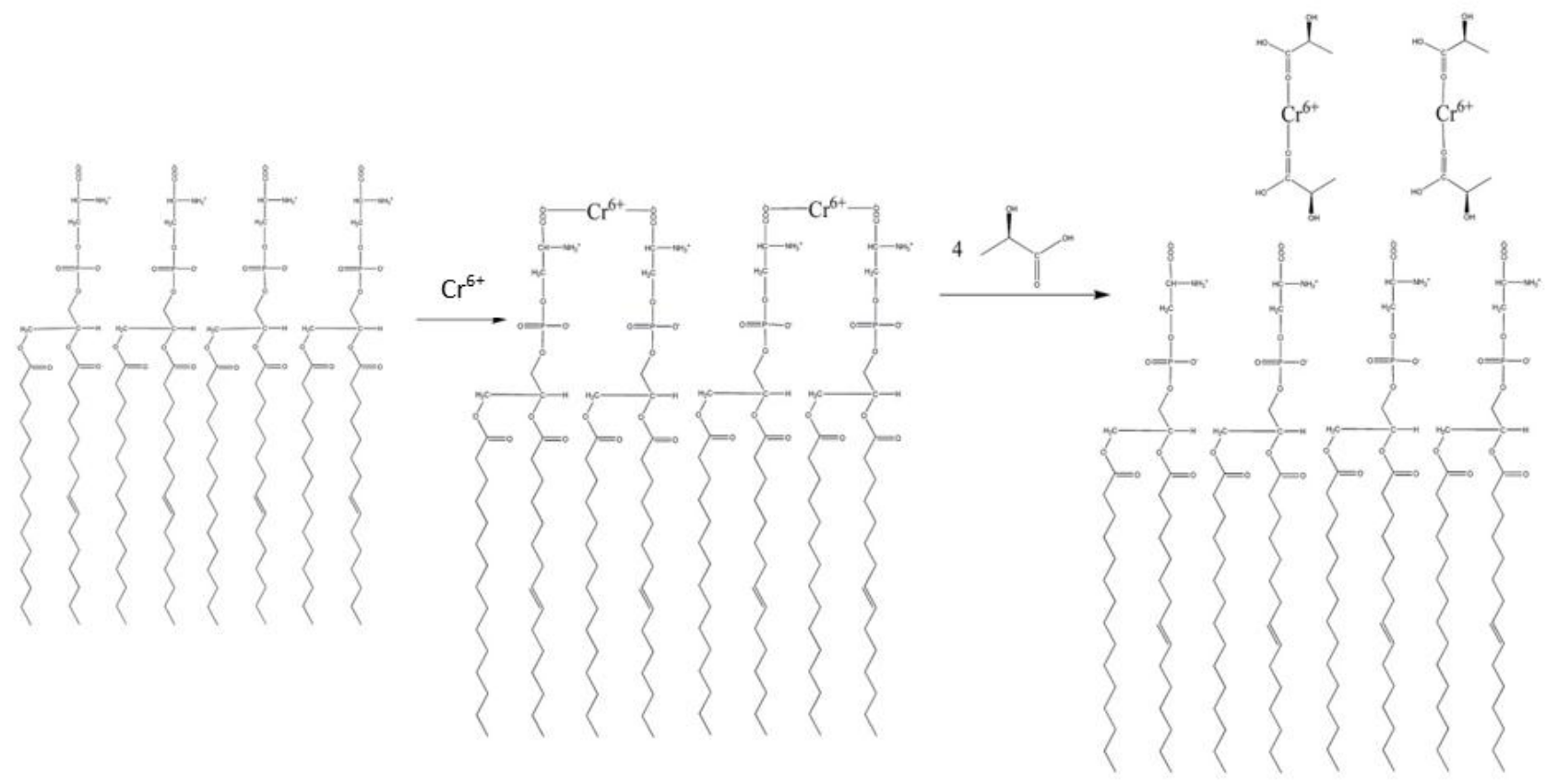

Fig 2. Hypothetical reactions between chromium and microbial cell walls

The soil that has been used to conduct bioremediation was tested using an infrared (IR) spectroscopy instrument to see functional groups changes that occur on the soil. Figure 2 is an IR spectrum from the soil before and after use for bioremediation.

Based on spectrum in figure 2, it appears that the functional groups between the soil before and after bioremediation are the same. However, after being used, the peak loss occurred in the wave number area of $1900 \mathrm{~nm}^{-1}$. The wave number is an area of metals (M-H stretching) [25]. This shows the loss of heavy metals in the soil. Heavy metals have been bound by microbes that develop in compost

\section{CONCLUSION}

Based on the obtained results then compost can be used as a bioremediatory. The use of compost can reduce heavy metals $\mathrm{Cd}$ and $\mathrm{Cr}$ with the highest chromium reduction of $92.222 \%$ and the highest cadmium by $90.5517 \%$ in the use of $25 \%$ compost for 14 days.

\section{ACKNOWLEDGMENT}

The thanks were conveyed to the Dean of the Mathematics and Natural Sciences Faculty of Surabaya State University who had funded this research through the Policy Research Fund of the Faculty of Mathematics and Natural Sciences.

\section{REFERENCES}

[1] Darmono, Logam Dalam Sistem Biologi Makhluk Hidup, Jakarta: Indonesia University Press, 1995.

[2] A. Nieto-Márqueza, A. Pinedo-Floresb, G. Picassoc, E. Atanesa, and R.S. Koub, "Selective adsorption of $\mathrm{Pb} 2+, \mathrm{Cr} 3+$ and $\mathrm{Cd} 2+$ mixtures on activated carbons prepared from waste tires," J. Envir. Chem. Eng., vol. 5, pp. 1060-1067, 2017.

[3] M. Dayton, R. Erin, B. Matthew, and L. Igor, "Resilience and sustainability: Similarities and differences in environmental management applications," Sci. of the Total Environ., vol. 613, pp.1275$1283,2017$.

[4] P.L. Palaniappan and S. Karthikeyan, "Bioaccumulation and depuration of chromium in the selected organs and whole body tissues of freshwater fish Cirrhinus mrigala individually and in binary solutions with nickel," J. Environ. Sci., vol. 21, pp. 229-36, 2009.

[5] Y.S. Ok, H. Lee, J. Jung, H. Song, N. Chung, S. Lim, and J.G. Kim, "Chemical characterization and bioavailability of cadmium in artificially and naturally contaminated soils," Agr. Chem. Biotechnol., vol. 47, pp. 143-146, 2004.

[6] J. Soemirat, Toksikologi Lingkungan, Yogyakarta: Gadjah Mada University Press, 2009.

[7] I. Reijonen and H. Hartikainen, "Oxidation mechanisms and chemicalbioavailability of chromium in agricultural soil-pH as the master variable," Appl. Geochem., vol. 74, pp. 84-93, 2016.

[8] Palar and Heryando, Pencemaran dan Toksikologi Logam Berat, Jakarta: Rineka Cipta, 2012.

[9] Badan Standarisasi Nasional, "Standar Nasional Indonesia Bahan Beracun dan Berbahaya (B3)," 2004.

[10] C.R. Priadi, A.S. Putri, and S.S. Moersidik, "Adsorpsi Logam Seng dan Timbal pada Limbah Cair Industri Keramik oleh Limbah Tanah Liat," Reaktor, vol. 15, pp. 10-19, 2014.

[11] Rusmini, Muchlis, and Sukarmin, "Decrease of Heavy Metal Using Effective Microorganism 4 (EM4) As the Soil Bioremediation Effort," Res. J. of Pharm., Biol. and Chem. Sci., vol. 8, pp. 85-90, 2017.

[12] Y. Murni, I. Frendy, and P. Adiningsih, "Optimasi Kondisi Proses Pembuatan Kompos Dari Sampah Organik Dengan Cara Fermentasi Menggunakan EM4," J. Teknol., vol. 5, pp. 172-181, 2012.

[13] P. Eva, "Media- Efektivitas Kompos Batang Pisang (Musa Sp.) Untuk Meminimalisasi Kandungan Logam Berat Timah Hitam (Pb) Dan Menaikan pH Rendah Pada Media Budidaya Ikan Lele Dumbo (Clarias gariepinus)," Akuatik: J. Sumberd. Perair., vol. 7, pp. 1-8, 2013.

[14] W. Basuki and S. Agustina, "Pengaruh Pemberian Pupuk Kompos terhadap Pertumbuhan Semai Mahoni (Swietenia macrophylla King.) pada Media Tanah Bekas Tambang Emas (Tailing)," J. Silvik. Tropika, vol. 3, pp. 109-112, 2011. 
[15] I.R. Lesmanawati, "Pengaruh pemberian kompos thiobacillus, dan penanaman gmelina serta sengon pada tailing emas terhadap biodegradasi sianida dan pertumbuhan kedua tanaman," unpublished.

[16] Suhendrayatama, "Heavy Metal Bioremoval by Microorganism; a Literature Study," [Online], Available: http://www.istecs.org/Publication /japan/010211. 2001. [Accessed: 30-Jul-2018].

[17] E. Widyati, "Peran Mikroba Tanah Pada Kegiatan Rahabilitasi Lahan Bekas Tambang," Info Hutan, vol. 2, pp. 151-160, 2008

[18] S.W.C. Chien, C.C. Huang, and M.C. Wang, "Analytical and spectroscopic characteristics of refuse compost-derived humic substances," Int. J. Appl. Sci. and Eng., vol. 1, pp. 62-71, 2003.

[19] J. Hermana, and E. Nurhayati, "Removal of $\mathrm{Cr} 3+$ and $\mathrm{Hg} 2+$ using compost derived from muncipal solid waste," Sustain. Environ. Res., vol. 20 , pp. 257-261, 2010.
[20] E.N. Khasanah, “Adsorpsi logam berat,” Oseanan, vol. 4, pp. 1-7, 2009.

[21] J. Hermana, and E. Nurhayati, "Potensi kompos sebagai media penukar ion untuk mereduksi logam berat dalam air limbah," J. Purifikasi, vol. 7, pp. 169-174, 2006.

[22] G. Kucasov and Z. Guvener, "Efficiency of compost in the removal of heavy metals from the industrial wastewater," Environ. Geol., vol. 57, pp. 291-296, 2009.

[23] X. Guo, S. Zhang, and X.Q. Shan, "Adsorption of metal ions on lignin," J. of Hazard. Mater., vol. 151, pp. 134-142, 2008.

[24] Y. Wu, S. Zhang, X. Guo, and H. Huang, "Adsorption of chromium(III) on lignin," Bioresour. Technol., vol. 99, pp. 7709-7715, 2008.

[25] B.H. Stuart, Infrared spectroscopy: Fundamentals and applications, US: Wiley, 2004. 